\title{
Choosing a fashion program: the relevant criteria
}

\begin{abstract}
Technology and reality television has produced a unique platform for fashion programs (Pavlushina \& Dautova, 2017). ${ }^{1}$ Wearable computing and e-textiles has witnessed rapid development over recent years (Lau, Ngai, Chan \& Cheung, 2009). ${ }^{2}$ With ever-changing, cutting-edge technology available, a career in the fashion industry is not limited to fashion centers, but is a viable option for students across the country. As students become more technologically savvy, they expect an education based on the newest technology available. The present study examined the views of college students in fashion program on the criteria perceived as most important in selecting a fashion program. The results indicated that students viewed faculty with experience in the industry, high job placement, and program reputation as the most important factors in selecting a fashion program. Interestingly, students indicated that having a friend in the fashion program was somewhat important, while domestic and international travel was very important the study also observed individual differences in the perceived importance of the criteria based on gender, class, major and years of experience in the fashion industry.
\end{abstract}

Keywords: fashion programs, curriculum, recruitment, perspective students
Volume 5 Issue I - 2019

\author{
Jenifer Roberts,' Cathy Starr,' Dane \\ Peterson $^{2}$ \\ 'Merchandising and Fashion Design, Missouri State University, \\ USA \\ ${ }^{2}$ Management and Information Technology, Missouri State \\ University, USA
}

\begin{abstract}
Correspondence: Dr. Jenifer Roberts, Merchandising and Fashion Design, Research conducted at Missouri State University, 90 I S. National Ave, Springfield, MO 65898, USA, Tel 417-836-5000,Email jeniferroberts@missouristate.edu
\end{abstract}

Received: October 18, 2018 | Published: January 17, 2019

\section{Introduction}

Enrollment in fashion programs are at an all-time high (Pavlushina \& Dautova 2017). ${ }^{1}$ Increased interest in fashion programs has been partially attributed to the growing popularity of fashion-themed reality television shows. As interest in careers in the fashion industry has grown, the competition among university fashion departments to attract quality students has also escalated. To attract quality students, fashion programs recognize that they must distinguish themselves from other programs by offering an educational experience that is highly aligned with students' expectations. A recent inquiry sent to the International Textiles and Apparel Association revealed that there is presently no accurate record regarding the criteria students use in selecting a fashion program. Thus, a pertinent research issue involves the identification of the major factors that affect students' decisions regarding the selection between various fashion programs. This survey study examined the criteria students view as most important when selecting a fashion program and asked students to rate the most desirable characteristics of a fashion program. Evidence relating to the characteristics that students' perceive as important for selecting a fashion program provides useful information on how resources should be most effectively allocated to developing an attractive program.

\section{Factors affecting educational choice}

Choosing among various college programs is an incredibly difficult choice for individuals as it is often a major determinate in the lifelong career of the individual. Poynton \& Lapan $^{3}$ asserted that educational decisions are critical markers for postsecondary success. Given the significance of educational choices, a number of studies have investigated the factors that affect the decision making process. For instance, one study found that faculty reputation, course variety, and ease of learning were the most important factors affecting decisions regarding the selection of a college program (Beggs et al., 2008). ${ }^{4}$ June ${ }^{5}$ reported that the five most important considerations in the choice of a college program are the facilities in which the program is housed, library facilities, sophisticated technology, classroom characteristics, and residence halls. Malgwi et al. ${ }^{6}$ reported that the most influential factor in choosing a college program was the students' interest in the subject, followed by aptitude in the subject, level of pay, and the college's reputation in the field. Asher \& Crawford ${ }^{7}$ observed that a number of factors influence the selection of a college program, including job placement, advisement system, tuition, and class size. Several studies have noted the importance of interest in subject, intellectual motivation, program advisors, and self-efficacy. ${ }^{8,9}$

Although prior studies have provided useful information on the criteria individuals use to select a college program, a search of a variety of university research data bases revealed little to no information specifically related to the criteria used by fashion students in the selection of a fashion program. Identifying the criteria students use to select among various fashion programs could benefit administrators in charge of establishing the appropriate curriculum and the optimal allocation of limited resources to enhance the program.

Students are undoubtedly looking for programs which are seen as being most advantageous to furthering their chosen career. There are a number of factors specifically related to fashion programs that may have a significant influence on the selection process. For instance, it would seem feasible that the department or college in which the fashion program is located could have an impact on how potential students view the program. That is, the perceived orientation and emphasis of the fashion program could be influenced by where the program is located within the university's organizational chart. Approximately $13 \%$ of fashion programs are administered in the College of Design or Art, offering a Bachelor of Arts Degree, while 36\% are administered by College of Health and Human Sciences, offering a Bachelor of Science Degree; $25 \%$ from the College of Agriculture, offering a Bachelor of Science Degree; 18\% from College of Education and Human Sciences, offering a Bachelor of Science Degree; $8 \%$ from the College of Business, offering a Bachelor of Science Degree ("Fashion-School.org", 2018). ${ }^{10}$ The current study examined how potential students view where the fashion program is housed in terms of selecting a fashion program.

Another potentially important criterion in the selection process is the technology used in the classes. Success in the fashion industry is likely to rely on the student's knowledge on the most relevant and up to date technology. Knowledge regarding the technology that is perceived as most vital by students could be useful to fashion program administrators as a tool for optimal resource allocation. 
For fashion programs, student competitions and internships have proven to be extremely beneficial. Lafrenz \& Murray ${ }^{11}$ reported that competitions encourage students' independence, personal growth, and self-directed learning. Similarly, internships provide student in the fashion industry with a number of potential benefits (Olsen, 2017). ${ }^{12}$ For instance, internships provide students with the opportunity to engage in their field of study, an understanding of the financial rewards, working environment, prestige, and perceived overall quality of life. Internships can also play a key role in fostering professional connections. Thus, the present study will investigate the importance of issues related to student competitions and internships in terms of the fashion program selection process.

It would seem reasonable that individual characteristics and personal background could influence which criteria are viewed as most important criteria for selecting a fashion program. An abundance of research has demonstrated individual differences on a wide array of personal traits across various types of decision making processes (Heilman, 2006)..$^{13}$ There appears to be little relevant research on individual differences with respect to the perceived importance of various criteria in selecting a fashion program. Therefore, this study will explore possible differences based on gender, class, amount of work experience, and major emphasis of study (merchandising or design).

\section{Methodology}

A self-administered questionnaire was completed by 208 students enrolled in several fashion and design classes offered at a large Midwest university. Students were asked to rate the importance of 28 characteristics that may influence their choice of a fashion program. Each item was rated based on a Likert scale with five responses;
1) Unimportant
2) Not very important
3) Somewhat important
4) Important
5) Very important.

Twelve of the characteristics included in the survey involved general issues regarding program desirability taken from previous studies. This included items on tuition, class size, job placement, program and faculty reputation, faculty experience among others. Three survey items pertain to the college in which the fashion program is located (College of Business, Arts and Letters, Natural and Applied Sciences). Seven items were related to technology used in fashion programs including Adobe Illustrator, Adobe Photo Shop, Kaledo, TC2 Body Scanner, Melco Embroidery Machine, Direct Garment Printer, and Visual Merchandising Software. The final six items relate to experiential learning in fashion programs. This included Domestic and International Study tours, Out of State and Instate Internships, Student Competition and Fashion Shows out of the Department. Students were also asked for their current year in the program, their gender, their number of years of work experience, their current degree (merchandising, design or both) and their current GPA.

\section{Results}

The means and standard deviations for each of the 28 criteria are presented in Table 1. As can be seen in Table 1 Faculty with Industry Experience (4.84), High Student Placement (4.84), and Reputation of the Fashion Program (4.70) were viewed as the most important criteria. With respect to the college that houses the fashion program, the College of Business (4.43) was clearly preferred to fashion programs housed in either the College of Arts and Letters (3.16) or College of Natural and Applied Sciences (2.79). For the technology related items, Adobe Photo Shop (4.53) was perceived to be the most important, followed by Using Visual Merchandising Software in the Classroom (4.29), Adobe Illustrator (4.25), Kaledo (4.13), TC2 Body Scanner (4.12), Direct Garment Printer (4.05), and Melco Embroidery Machine (3.93). The results for the experiential learning items indicated Fashion Shows outside the Department (4.46) received the highest rating. Domestic (4.38) and Foreign (4.29) Study Tours were rated more important than Out-of-State (3.88) and Instate (3.86) Internships.

Table I Importance of Criteria in Choosing a Fashion Program

\begin{tabular}{|c|c|c|}
\hline Criteria importance & Mean & $\begin{array}{l}\text { Standard } \\
\text { deviation }\end{array}$ \\
\hline 1. Fashion Professors with Industry Experience & 4.84 & 0.484 \\
\hline 2. High Student Placement & 4.84 & 0.503 \\
\hline 3. Reputation of the Fashion Program & 4.7 & 0.672 \\
\hline 4. Academic Advisors Accessible within the Program & 4.6 & 0.774 \\
\hline 5. Adobe Photo Shop & 4.53 & 0.701 \\
\hline 6. Fashion Shows Outside the Fashion Department & 4.46 & 0.766 \\
\hline 7. Reasonable Tuition & 4.44 & 0.895 \\
\hline 8. Small Class Sizes & 4.43 & 0.783 \\
\hline 9. Fashion Dept. housed in the College of Business & 4.43 & 0.985 \\
\hline 10. Domestic Study Tours & 4.38 & 0.705 \\
\hline 11. Foreign Study Tours & 4.29 & 0.802 \\
\hline 12. Using Visual Merchandising Software & 4.29 & 0.948 \\
\hline 13. Adobe Illustrator & 4.25 & 0.803 \\
\hline 14. Student Competitions & 4.23 & 0.613 \\
\hline 15. Involvement in Student Organizations & 4.18 & 0.923 \\
\hline 16. Importance of Community Involvement & 4.15 & 0.891 \\
\hline 17. Using Kaledo in Class & 4.13 & 1.04 \\
\hline 18. Using TC2 Body Scanner in Class & 4.12 & 0.865 \\
\hline 19. Using Direct Garment Printer in Class & 4.05 & 0.899 \\
\hline 20. Using Melco Embroidery Machine in Class & 3.93 & 0.988 \\
\hline 21. Out of State Internship & 3.88 & 1.15 \\
\hline 22. Instate Internship & 3.86 & 1.03 \\
\hline $\begin{array}{l}\text { 23. Academic Advisors Accessible in College } \\
\text { Advisement Center }\end{array}$ & 3.85 & 1.206 \\
\hline 24. Having Friends Majoring in Fashion & 3.72 & 1.255 \\
\hline 25. Classes Located on Campus & 3.52 & 1.239 \\
\hline 26. Classes Located Offsite of the Main Campus & 3.23 & 1.283 \\
\hline $\begin{array}{l}\text { 27. Fashion Dept. housed in College of Arts \& } \\
\text { Letters }\end{array}$ & 3.16 & 1.333 \\
\hline $\begin{array}{l}\text { 28. Fashion Dept. housed in College of Natural \& } \\
\text { Applied Sciences }\end{array}$ & 2.79 & 1.209 \\
\hline
\end{tabular}


Statistical tests were conducted to explore potential individual differences with respect to the perceived importance of the 28 criteria. As for gender, the majority of the respondents were female (Female $\mathrm{n}=187$; Male $\mathrm{n}=11$ ). Independent samples t-tests on the 28 items indicated a significant difference for two of the items. The results are illustrated in Table 2. The female respondents rated High Student Placement ( $\mathrm{t}=3.21, \mathrm{p}=.002)$ and Reputation of the Fashion Program $(\mathrm{t}=2.74, \mathrm{p}=.007)$ as significantly more important than did the male students.

A one-way ANOVA was conducted on the 28 items based on the respondent's year in college. The results are summarized in Table 3. Most of the items that produced a significant result are related to technology. As can be seen in Table 3, freshmen, sophomores, and juniors generally rated the technology items as more important than did the seniors. Similar results were observed for Student Competitions $(\mathrm{F}=2.90, \mathrm{p}=.036)$ and Out of State Internships $(\mathrm{F}=3.81, \mathrm{p}=.011)$.

To investigate the influence of respondents' years of work experience, the variable was classified into four categories; no work experience, 1-2 years, 3-4 years, and 5 or more years of work experience. A one-way ANOVA was conducted on each of the 28 items. The results are displayed in Table 4. As shown in Table 4, several of the items related to technology were significant with individuals having the most experience rating the technology items as less important. However, the respondents with most experience rated the housing the fashion program within the College of Business as more important than did respondents with less experience $(\mathrm{F}=2.45$, $\mathrm{p}=.065)$. Likewise, the respondents with the most experience rated Reputation of the Fashion Program as significantly more important $(\mathrm{F}=6.28, \mathrm{p}<.001)$.

Students participating in this survey had opted for a major in merchandising $(\mathrm{n}=130)$ or design $(\mathrm{n}=35)$. A few of the participants choose to major in both options $(n=6)$, while small number choose fashion as one part of a double major $(n=4)$. The results of one-way ANOVAs based on major are presented in Table 5. Table 5 shows that students majoring in merchandising rated Housed in the College of Business, High Student Placement, Reputation of Fashion Program, Domestic and Foreign Study Tours as more important than did students majoring in design.

Table 2 Gender Differences and Mean Perceived Importance of Criteria

\begin{tabular}{lllll}
\hline \multirow{2}{*}{ Criteria } & \multicolumn{2}{l}{ Gender } & & \\
\cline { 2 - 5 } & Males (n=11) & Females (n=187) & t-statistic & P-value \\
\hline High Student Placement & 4.36 & 4.86 & 3.21 & 0.002 \\
Reputation of Fashion Program & 4.27 & 4.77 & 2.74 & 0.007 \\
\hline
\end{tabular}

Table 3 Class Differences and Mean Perceived Importance of Criteria

\begin{tabular}{|c|c|c|c|c|c|}
\hline Criteria & $\begin{array}{l}\text { Freshman } \\
(n=35)\end{array}$ & $\begin{array}{l}\text { Sophomore } \\
(n=62)\end{array}$ & $\begin{array}{l}\text { Junior } \\
(n=60)\end{array}$ & $\begin{array}{l}\text { Senior } \\
(n=50)\end{array}$ & F-value \\
\hline Melco Embroidery Machine & 4.31 & 3.9 & 4.02 & 3.6 & $3.96^{*}$ \\
\hline TC2 Body Scanner & 4.34 & 4.21 & 4.23 & 3.74 & $4.84^{*}$ \\
\hline Kaledo & 4.43 & 4.31 & 4.25 & 3.58 & $9.93 *$ \\
\hline Adobe Illustrator & 4.26 & 4.2 & 4.5 & 4.04 & $3.29 *$ \\
\hline Direct Garment Printer & 4.4 & 4.1 & 4.15 & 3.64 & $5.97 *$ \\
\hline Visual Merchandising Software & 4.57 & 4.13 & 4.12 & 3.88 & $3.85^{*}$ \\
\hline Student Competition & 4.37 & 4.39 & 4.24 & 3.94 & $2.90 *$ \\
\hline Out of State Internship & 4.29 & 4.03 & 3.53 & 3.82 & $3.81 *$ \\
\hline
\end{tabular}

$* \mathrm{P}$-value $<.05$

Table 4 Work Experience and Mean Perceived Importance of Criteria

\begin{tabular}{|c|c|c|c|c|c|}
\hline \multirow[b]{2}{*}{ Criteria } & \multicolumn{5}{|c|}{ Years of work experience } \\
\hline & $\begin{array}{l}\text { None } \\
(n=50)\end{array}$ & $\begin{array}{l}1-2 \\
(n=52)\end{array}$ & $\begin{array}{l}3-4 \\
(n=46)\end{array}$ & $\begin{array}{l}5 \text { or more } \\
(n=57)\end{array}$ & F-value \\
\hline Melco Embroidery Machine & 3.83 & 4.1 & 4.11 & 3.68 & $2.34 *$ \\
\hline Kaledo & 4.12 & 4.52 & 4.22 & 3.68 & $9.03 * *$ \\
\hline Direct Garment Printer & 4.15 & 4.21 & 4.11 & 3.79 & $2.47 *$ \\
\hline Housed in College of Business & 4.28 & 4.54 & 4.17 & 4.63 & $2.45^{*}$ \\
\hline Reputation of Fashion Program & 4.44 & 4.63 & 4.78 & 4.96 & $6.28 * *$ \\
\hline
\end{tabular}

$* \mathrm{P}<.10, * * \mathrm{p}<.05$ 
Table 5 Degree and Mean Perceived Importance of Criteria

\begin{tabular}{llllll}
\hline Criteria & $\begin{array}{l}\text { Merchandising } \\
(\mathbf{n = 1 3 0})\end{array}$ & $\begin{array}{l}\text { Design } \\
(\mathbf{n = 3 5})\end{array}$ & $\begin{array}{l}\text { Both options } \\
(\mathbf{n = 6})\end{array}$ & $\begin{array}{l}\text { Double major } \\
(\mathbf{n}=\mathbf{4})\end{array}$ & F-value \\
\hline Housed in College of Business & 4.68 & 3.97 & 4.17 & 5 & $7.86^{* *}$ \\
High Student Placement & 4.92 & 4.71 & 4.67 & 5 & $2.51^{*}$ \\
Reputation of Fashion Program & 4.87 & 4.54 & 3.5 & 4.25 & $14.56^{* *}$ \\
Domestic Study Tours & 4.49 & 4.17 & 4.17 & 4.25 & $2.29^{*}$ \\
Foreign Study Tours & 4.48 & 4.11 & 4.5 & 3 & $7.73^{* *}$ \\
\hline
\end{tabular}

$*_{p}$-value , .10,**p-value $<.05$

\section{Discussion}

The analysis described above, while based on a Midwest University, could provide an insight for other Fashion Programs throughout the country. This study allows faculty to better understand the needs of prospective fashion majors and delineates what students are looking for when selecting a fashion program. From a marketing perspective, the study better prepares the fashion programs to coordinate their curriculum and hands-on opportunities to attract prospective students.

When a student starts the process of selecting a college to attain a degree in fashion merchandising or design there are many factors for them to consider such as the reputation of the fashion department, types of internships, percentage of job placement, classroom industry equipment and software, as well as where the program is located within a college (e.g., Natural and Applies Science, Business, and Arts and Letters). The findings from respondents in this study deemed it important that fashion professors had industry experience (mean=4.84), job placement after graduation (mean=4.84), student competitions (mean=4.23), reasonable tuition (mean=4.44), and industry computer software and equipment used in the classroom. The importance of the use of industry computer software and equipment in the classroom is consistent with the regional and national rankings conducted by Fashion-Schools.org (2013) which ranks Midwest fashion programs in Ohio, Michigan, Indiana, Illinois, Wisconsin, Minnesota, Iowa, Missouri, Kansas, Nebraska, South Dakota, and North Dakota. The Fashion-School.org (2013) criterion for fashion and design programs is based on the academic reputation, admission selectivity, tuition value, geographical location, and depth and breadth of the program and faculty. It is noted that students who cannot attend schools in the fashion meccas of New York, Los Angeles, or other cities with distinct advantages choose universities that offer students the most opportunities when it comes to internships, networking opportunities, and curriculum ("Fashion-School.org", 2013; Granitz, Chen, \& Kohli, 2014). ${ }^{13,14}$

The findings proffer implications as to how fashion merchandising and design programs can position themselves when it comes to program recruitment. Even though the findings showed different preferences based on the students' current year in the program, gender, number of years of work experience, current degree (merchandising, design or both) and current GPA this can be a baseline for fashion merchandising and design programs. The emphasis would be placed on affordable tuition, personal touch advising and program placement; whereas, to retain the fashion merchandising and design students, the program would focus more on internships, faculty industry experience, and networking opportunities. ${ }^{15-21}$
For future research, we recommend a further study involving students who have completed an internship and evaluate class curriculum to real world industry experience. Assessing course content that was relevant and beneficial during their internship experience as well as what content is not being taught that would be beneficial upon graduation. This additional study would help fashion merchandising and design programs re-evaluate and revise curriculum, meet the ever-changing demands of the fashion industry as well as to offer a premier fashion program, even in the Midwest.

\section{Acknowledgments}

None.

\section{Conflicts of interest}

Author declares there is no conflict of interest in publishing the article.

\section{References}

1. Pavlushina MI, Dautova RV. Fashion TV and the motivation of his audience. Journal of History, Culture \& Art Research. 2017;6(4):479488 .

2. Lau WY, Ngai G, Chan SCF, et al. Learning programming through fashion design: a pilot summer course in wearable computing for middle school students. Proceedings of the $40^{\text {th }}$ ACM technical symposium on Computer Science Education. 2009:504-508.

3. Poynton TA, Lapan RT. Aspirations, Achievement, and School Counselors' Impact on the College Transition. Journal of Counseling \& Development. 2016;95(4):369-377.

4. Beggs JM, Bantham JH, Taylor S. Distinguishing the factors influencing college students' choice of major. College Student Journal. 2008;42(2):381-394.

5. June AW. Facilities play a key role in students' enrollment decisions, study finds. Chronicle of Higher Education. 2006;52(40):A27.

6. Malgwi CA, Howe MA, Burnaby PA. Influences on students' choice of college major. Journal of Education for Business. 2005;80(5):275-282.

7. Absher K, Crawford G. Marketing the community college starts with understanding students' perspectives. Community College Review. 1996;23(4):59-68.

8. Corts DP, Stoner A. The college motives scale: classifying motives for entering college. Education. 2011;131(4):775-781.

9. Schaub M. The Profession of college career services delivery: what college counselors should know about career centers. Journal of College Student Psychotherapy. 2012;26:201-215. 
10. Fashion Schools. Rankings and profiles of fashion schools. 2018

11. Lafrenz L, Murray B. Fostering self-directed learners through competitions. College Quarterly. 2005;8(3):1-12.

12. Olsen L. Schools equip students to break into fashion industry here's how fashion and design programs ensure their grads get noticed -- and placed. FN: Footwear News. 2017;73(36):24-24.

13. Heilman RM. The impact of emotions and individual differences upon economic decision-making: A Review of the Experimental Literature. Cognitie, Creier, Comportament/Cognition, Brain, Behavior 2006;10(3):439-459.

14. Granitz N, Chen S, Kohli KK. Choosing business as a college major: A survey of high school students. Journal of the Academy of Business Education. 2014;15(1):1-22.

15. Albanese CA, O'Neill K, Hines JD. Clothing and textile curricula in higher education. Journal of Family and Consumer Studies. 1998;90(4):88-91.
16. Fair NB, Hamilton JA, Norum PS. Textile knowledge for merchandising professionals: Significance for pedagogy in clothing and yextiles. Clothing and Textiles Research Journal. 1990;8(2):29-37.

17. Galotti KM, Kozberg SF. Older adolescents' thinking about academic/ vocational and interpersonal commitments. J Youth Adolesc. 1987;16 (4):313-330.

18. Holm LS. Fashion Function Future (F:3)-a research programme. Nordic Textile Journal. 2012:3-5.

19. Laughlin J, Kean RC. Assessment of textiles and clothing academic programs in the United States. Clothing and Textiles Research Journal. 1995;13(3):184-199.

20. New Fashion and Textiles Apprenticeship launched. Education (14637073). 2012;(465):6-7.

21. Wright J, Cushman L, Nicholson A. Reconciling industry and academia: Perspectives on the apparel design curriculum. Education + Training. 2002;44(3):122-128. 